\title{
Manajemen Anestesi untuk Tindakan Vp-Shunt pada Bayi Sindrom Crouzon dengan Hidrosefalus
}

\author{
Chrismas Gideon Bangun*), Rose Mafiana**), Syafruddin Gaus***) \\ ${ }^{*}$ SMF Anestesiologi dan Terapi Intensif RSUP H. Adam Malik Medan, ${ }^{* *}$ Departemen Anestesiologi \& \\ Terapi Intensif Fakultas Kedokteran Universitas Sriwijaya-RSUP Dr. M. Hoesin Palembang, ${ }^{* * *}$ Departemen \\ Anestesiologi \& Terapi Intensif Fakultas Kedokteran Universitas Hasanudin-RSUP Dr. Wahidin Makassar
}

\begin{abstract}
Abstrak
Sindrom Crouzon adalah sindrom dominan autosom yang ditandai dengan trias yaitu deformitas tengkorak, anomali wajah, dan eksoftalmus. Sindrom Crouzon memiliki prevalensi 1: 60.000 kelahiran. Sindrom ini disebabkan sinostosis dini sutura koronal dan sagital yang mengakibatkan dismorfisme wajah. Pada anestesi pasien dengan sindrom Crouzon, harus dilakukan langkah-langkah untuk antisipasi dan persiapan penanganan jalan napas yang sulit. Pada kasus ini, seorang bayi 5 bulan dengan sindrom Crouzon datang dengan keluhan kepala membesar sejak 2 bulan sebelum masuk rumah sakit. Dari CT-scan didapatkan hidrosefalus, dan dilakukan tindakan VPshunt. Telah diantisipasi adanya kesulitan intubasi, maka dilakukan persiapan alat-alat termasuk bougie anak. Bougie tersebut kemudian ternyata sangat berguna saat dilakukan intubasi ulang karena ketidaksesuaian ukuran tube endotrakeal. Operasi VP-shunt berjalan dengan baik, pasca operasi dan anestesi pasien sadar baik, respirasi dan hemodinamik stabil dan kemudian pindah ke ruang rawat biasa. Dalam penanganan pasien ini, antisipasi, peralatan difficult airway yang lengkap, rencana alternatif, serta pendekatan multidisiplin sangat diperlukan.
\end{abstract}

Kata kunci: Hidrosefalus, sindrom crouzon, VP-shunt

JNI 2019;8 (1): 44-9

\section{Anaesthetic Management for VP-Shunt in Baby Crouzon syndrome with Hydrocephalus}

\begin{abstract}
Crouzon syndrome is an autosomal dominant syndrome characterized by triad of skull deformity, facial anomalies, and exophthalmos. Crouzon syndrome has a prevalence of 1: 60,000 births. This syndrome is characterized by early synostosis of coronal and sagittal sutures which leads to facial dysmorphism. In Crouzon syndrome, steps must be taken to anticipate and prepare for difficult airway handling.In this case, a 5-month-old baby with Crouzon syndrome presents with an enlarged head complaint 2 months before being hospitalized. CT scan showed hydrocephalus was, and VP-shunt action was planned. It is anticipated that there will be difficulty in intubation, so preparations for tools including child bougie were made. Bougie then turned out to be very useful because it had to be re-intubated because of the incompatibility of the size of the endotracheal tube. VP-shunt surgery works well, surgery and anesthesia were uneventful, then patient moved to the ward. Anticipation, complete difficult airway equipment and alternative plans, as well as a multidisciplinary approach are needed in handling these patients.
\end{abstract}

Key words: Crouzon syndrome, hydrocephalus, VP-shunt

JNI 2019;8 (1): 44-9 


\section{Pendahuluan}

Sindrom Crouzon adalah kelainan dominan autosom yang langka, dengan prevalensi 1:60 000 kelahiran hidup. Variabel ekspresi gen, yang mengarah ke variasi dalam presentasi fenotipik didapatkan. ${ }^{1,2}$ Mutasi gen fibroblast growth factor 2 (FGFR2), yang bertanggung jawab atas kondisi ini, juga ditemukan dalam sindrom Apert, sindrom Pfeiffer dan Sindrom Jackson-Weiss. ${ }^{3,4}$ Sindrom Crouzon ditandai oleh disostosis kraniofasial, yang meliputi tiga yaitu: kelainan bentuk tengkorak, anomali wajah dan eksoftalmus. Sindrom ini meliputi sekitar 4,8\% dari semua kasus kraniosinostosis (penutupan prematur kranium), dan tidak ada kecenderungan ras atau jenis kelamin. ${ }^{5}$ Sindrom ini biasanya terdeteksi saat lahir atau masih bayi. Ciri fiturfitur dismorfik dapat dengan mudah terlihat. Deformitas kraniofasial terjadi terutama karena perbedaan tingkat dan waktu penutupan sutura tengkorak, menghasilkan penutupan prematur atau terlambat, menyebabkan berbagai kelainan dan deformitas wajah. ${ }^{5}$ Fitur-fitur dismorfik ini dapat menjadi lebih menonjol, atau menunjukkan regresi seiring bertambahnya usia. Fitur-fitur ini termasuk eksoftalmus, hipertelorisme, strabismus, hipoplasia maksila, hidung paruh dengan kompresi septum hidung, cacat bibir, prognatisme mandibula, atrofi optik, dan gangguan visual. ${ }^{5}$ Pasien dengan sindrom Crouzon dapat disertai dengan hidrosefalus, kejang, dan retardasi mental. Insidens hidrosefalus pada kraniosinostosis berkisar antara $4-26 \%{ }^{6}$

\section{Kasus}

\section{Alloanamnesis}

Pasien seorang bayi perempuan berumur 5 bulan dengan berat badan $5,5 \mathrm{~kg}$ datang dengan kepala membesar sejak 2 bulan sebelum masuk rumah sakit. Pasien anak pertama, lahir normal, berat lahir 3,2 kg, lahir di bidan tanpa resusitasi aktif. Riwayat operasi sebelumnya tidak ada. Tidak ada demam/batuk/pilek. Tidak ada mual/muntah. Tidak ada kejang. Tidak ada alergi obat.

\section{Pemeriksaan Fisik}

Pada pemeriksaan prabedah didapatkan keadaan umum sadar baik, laju nafas 26 kali per menit, laju nadi 130 kali per menit, suhu $37,6{ }^{\circ} \mathrm{C}$ dan $\mathrm{SpO}_{2} 97 \%$ dengan udara bebas. Pada pemeriksaan kepala didapatkan ubun-ubun besar menonjol, lingkar kepala $52 \mathrm{~cm}$, frontal bossing, dan terdapat venektasi. Pada mata dijumpai shallow eye sockets, bulging eyes, konjungtiva tidak anemis, dan sklera tidak ikterik. Pada konjungtiva pasien didapatkan injeksi/infeksi konjungtiva disertai sekret serta didapatkan keratitis exposure. Pada mulut dijumpai high arch palate. Pemeriksaan jantung, paru, abdomen dan ekstremitas dalam batas normal.

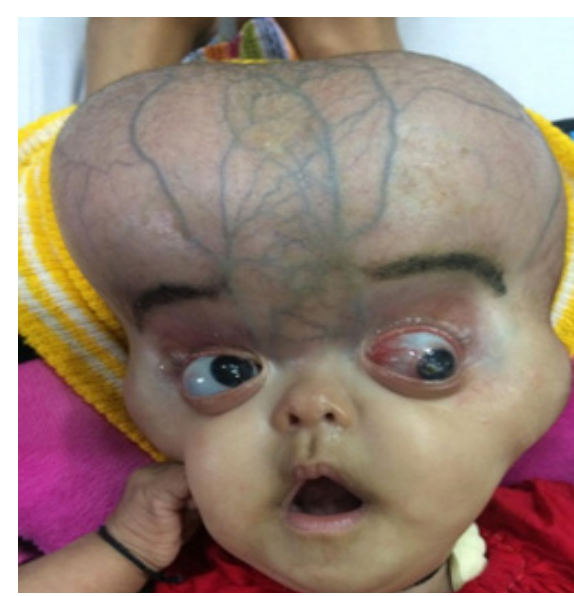

Gambar 1. Pasien saat Kunjungan Preoperasi

\section{Pemeriksaan Laboratorium}

Hasil pemeriksaan laboratorium menunjukkan hiponatremia, oleh sejawat pediatrik dilakukan koreksi hiponatremia dengan kapsul $\mathrm{NaCl}$ selama 2 hari. Pemeriksaan laboratorium lainnya dalam batas normal.

\section{CT-Scan}

Dilatasi ventrikel lateral bilateral, ventrikel 3, kornu temporal lebih dari $2 \mathrm{~mm}$, Evans ratio lebih dari 0,3 (gambar 2).

Pasien digolongkan ASA 2 dengan peningkatan TIK ec hidrosefalus, hiponatremia $127 \mathrm{mEq} / \mathrm{L}$, leukositosis 16.310/mm3 dan kemungkinan sulit airway (sindrom Crouzon)

\section{Tindakan Anestesi}

Pasien dibawa ke ruang operasi dengan jalur 

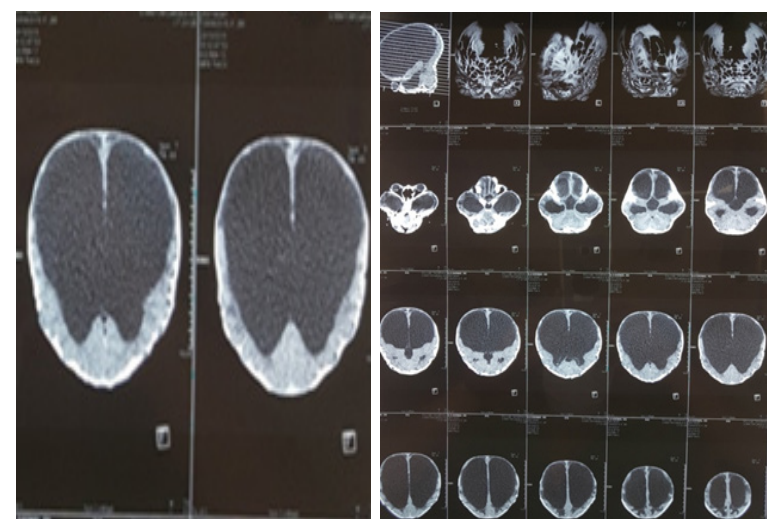

Gambar 2. CT-Scan Pasien Menggambarkan dilatasi Ventrikel Lateral Bilateral dan Ventrikel 3.

intravena 24G terpasang di kaki kiri dan CVC $3,0 \mathrm{~F}$ di vena femoralis kanan. Pasien tidak diberikan premedikasi. Dikarenakan ukuran kepala yang besar leher menjadi fleksi bila pasien dibaringkan mendatar di meja operasi. Badan pasien dari dada ke bawah diganjal dengan lipatan kain, agar leher dalam posisi netral. Pasien dipasang monitor EKG, tekanan darah non invasif, saturasi oksigen, dan diberi alas penghangat. Pasien diinduksi anestesi dengan menggunakan fentanyl 10 mikrogram dilanjutkan dengan propofol $5 \mathrm{mg}$ dan atracurium $2 \mathrm{mg}$. Saat laringoskopi didapatkan pita suara tidak kelihatan seluruhnya, hanya bagian posterior. Bougie dimasukkan melewati pita suara dan ett nomor 3,5 noncuff dimasukkan melalui bougie. Tindakan auskultasi dilakukan untuk memastikan posisi dan kedalaman ETT, dilakukan fiksasi pada $12 \mathrm{~cm}$ di sudut bibir. Ventilator di-setting dengan tidal volume $35 \mathrm{cc}$ dan frekuensi nafas

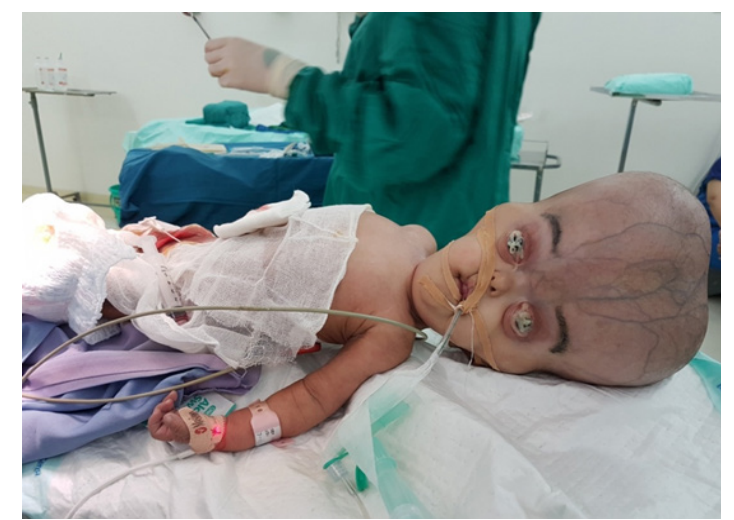

Gambar 4. Pasien setelah Intubasi

26 kali per menit, PEEP $5 \mathrm{mmHg}$. Pada ventilasi dengan tekanan $15 \mathrm{~cm} \mathrm{H}_{2} \mathrm{O}$ ditemukan kebocoran udara di trakea dan pembacaan etCO ${ }_{2}$ tidak sesuai. Diputuskan untuk mengganti ETT dengan ukuran lebih besar, bougie dimasukkan melalui ETT, ETT 3,5 diganti dengan 4,0 noncuff. Setelah auskultasi untuk memastikan posisi dan kedalaman ETT dilakukan tes kebocoran, tidak dijumpai kebocoran pada ventilasi dengan tekanan $17 \mathrm{~cm} \mathrm{H}_{2} \mathrm{O}$. Kondisi pasien setelah intubasi dapat dilihat pada gambar 4. Rumatan anestesi menggunakan sevoflurane $1-1,5 \mathrm{vol} \%$ dan $\mathrm{O}_{2}+$ udara $50 \%$. Selama operasi respirasi dan hemodinamik stabil. Operasi berlangsung selama 1 jam. Cairan masuk 75 cc. Perdarahan sekitar 5 $\mathrm{cc}$ dan urin output $5 \mathrm{cc}$. Monitoring selama operasi dapat dilihat pada gambar 3. Prosedur ekstubasi dilakukan pada kondisi sadar penuh di ruang operasi, dengan nadi 130 kali per menit, laju nafas 26 kali per menit, dan suhu $36{ }^{\circ} \mathrm{Cderajat}$ Celcius. Pasien diobservasi kesadaran dan nafas selama

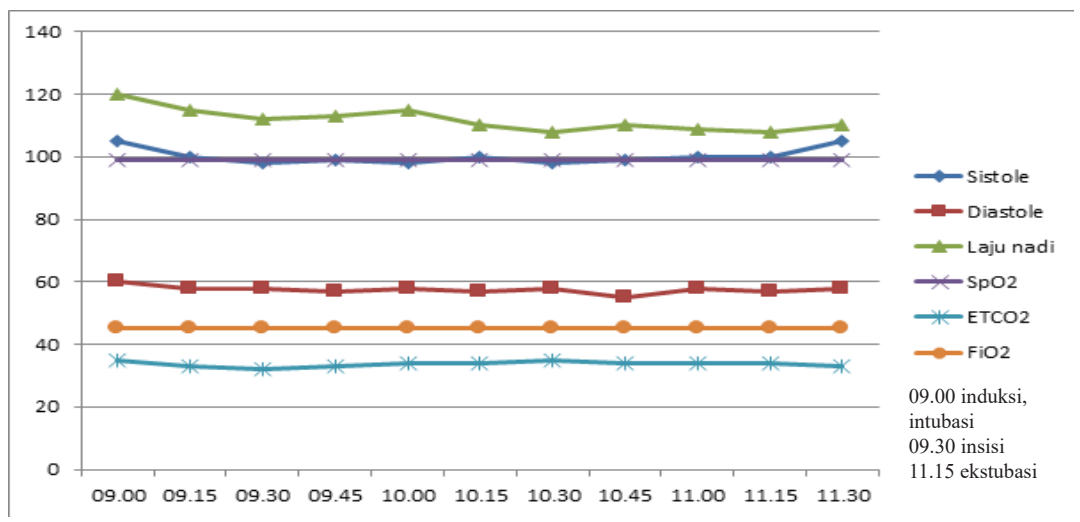

Gambar 3. Monitoring Selama Operasi. 
2 jam, kemudian pasien dipindahkan ke ruangan dengan Aldrette score 10. Pasca operasi diberikan Paracetamol $100 \mathrm{mg} / 6$ jam, Ondansetron $0,5 \mathrm{mg} / 8$ jam.

\section{Pembahasan}

Suatu studi retrospektif terhadap 1727 kasus kraniosinostosis dilakukan untuk mengetahui hubungan antara abnormalitas hidrodinamik cairan serebrospinal dan kraniosinostosis. Ditemukan abnormalitas hidrodinamik cairan serebrospinal pada $8,1 \%$ pasien. Tiga tipe gangguan hidrodinamik cairan serebrospinal telah diamati: hidrosefalus progresif dengan dilatasi ventrikel, ventrikulomegali nonprogresif, dan dilatasi ruang subarakhnoid. Hidrosefalus terjadi lebih sering pada kraniosinostosis sindromik $(12,1 \%)$ daripada yang hanya mengalami kraniosinostosis (nonsindromik) sebesar $0,3 \%{ }^{6}$

Peran hipertensi vena sebagai mekanisme terjadinya hidrosefalus pada pasien dengan kraniosinostosis telah dideskripsikan. ${ }^{7}$ Stenosis foramen jugular dan sempitnya fossa posterior adalah 2 faktor utama yang menyebabkan hidrosefalus pada sindrom Crouzon dan deformitas Kleeblattschadel. ${ }^{7}$

Tekanan intrakranial normal pada bayi sebesar 2-4 $\mathrm{mmHg}$, lebih rendah dibandingkan orang dewasa di mana tekanan intrakranial berkisar antara 8-15 $\mathrm{mmHg}$. Batas autoregulasi otak secara signifikan lebih rendah dengan tekanan darah arteri rata-rata 20-60 mmHg. Margin keselamatan lebih sempit karena bayi kurang mampu mengkompensasi perubahan tekanan darah. Usia anak memiliki aliran darah otak global yang lebih tinggi dibandingkan orang dewasa, tetapi pada bayi cukup bulan maupun bayi prematur lebih rendah. Bayi berisiko mengalami iskemia saat tekanan arteri rendah, sedangkan hipertensi sistemik dapat mengakibatkan perdarahan intraventrikular.

Oleh karena itu fluktuasi tekanan darah sistemik yang besar sebaiknya dihindari. Respons terhadap hiperventilasi dapat berlebihan dan iskemia dapat terjadi pada level $\mathrm{PCO}_{2}$ yang sangat rendah $(<20 \mathrm{mmHg}) .{ }^{8}$ Pada pembedahan pintas ventrikuloperitoneal, posisi biasanya telentang, kepala diputar ke sisi kontralateral dari tempat penyisipan shunt. Fleksi leher dapat menyebabkan migrasi ETT ke bronkus utama atau dapat membendung vena jugularis sehingga menghalangi drainase vena dan menyebabkan peningkatan volume dan tekanan intrakranial. Penanganan ekstra harus dilakukan untuk mengamankan ETT di posisi ini. Gulungan handuk bisa diletakkan di bawah bahu untuk memfasilitasi garis lurus dari telinga/leher ke perut untuk tunneling shunt. Mata harus dilindungi dari kekeringan dan cedera. ${ }^{8}$ Secara umum, rumatan anestesi dicapai dengan keseimbangan opioid, anestesi volatil dan pelumpuh otot. Sebagaimana telah diketahui, obat-obat anestesi volatil dapat menyebabkan vasodilatasi otak dan meningkatkan tekanan intrakranial. Isoflurane dan sevoflurane tampaknya memiliki efek minimal pada aliran darah otak dan reaktivitas serebrovaskular terhadap $\mathrm{CO}_{2}$ pada konsentrasi 0,5-1,5 MAC. Opioid kerja pendek seperti fentanil, alfentanil, sufentanil atau remifentanil, dapat memberikan analgesia intraoperatif yang memadai dengan mula kerja yang cepat dan durasi yang dapat diprediksi, memungkinkan penilaian neurologis pasca operasi yang tepat. ${ }^{8}$

Untuk melindungi mata intraoperasi diperlukan perhatian ekstra. Eksoftalmus dapat dijumpai dan penutupan kelopak mata bisa sulit. Sebaiknya digunakan lubrikasi dan penutup mata diletakkan dengan hati-hati. Dalam pengelolaan bedah saraf pada pasien pediatrik, pengendalian suhu merupakan pertimbangan penting. Hipotermia ringan sampai sedang memang bersifat neuroprotektif dan mungkin terapeutik pada adanya iskemia atau hipoksia. Namun pada bayi prematur dan bayi cukup bulan keadaan hipotermia dapat sangat meningkatkan konsumsi oksigen. Pada bayi, hipotermia dapat menyebabkan penurunan metabolisme obat, peningkatan produksi laktat dan asidosis metabolik, vasokonstriksi perifer, dan pergeseran kurva disosiasi $\mathrm{O}_{2}$-hemoglobin ke kiri. Komplikasi lain dari hipotermia termasuk pemanjangan efek anestesi, koagulopati, defisiensi imun dan kekacauan dalam metabolisme glukosa. Hipotermia berat juga dapat menyebabkan aritmia jantung. ${ }^{8}$ 
Manajemen cairan bertujuan terutama mempertahankan perfusi serebral, dengan mempertahankan isovolemia, isoosmolar dan isoonkotik. Normal saline $(\mathrm{NaCl} 0,9 \%)$ adalah kristaloid yang sering digunakan pada pasien gangguan saraf karena sifatnya yang sedikit hiperosmolar dapat mengurangi edema serebral.

Hiperglikemia dikaitkan dengan perburukan cedera otak akibat iskemia; karena itu, pemberian dekstrosa tidak dilakukan. Bayi, khususnya yang prematur berisiko lebih tinggi untuk mengalami hipoglikemia. Bayi-bayi prematur harus diukur gula darahnya secara berkala apabila menjalani prosedur lama dan bila pemberian dekstrosa memang diinndikasikan. Pada pasien dengan hipertensi intrakranial, obat-obatan untuk menurunkan tekanan intrakranial dapat digunakan. Furosemide, suatu loop diuretik, sering dipakai untuk menimbulkan diuresis dan mengurangi produksi cairan serebrospinal. Terapi hiperosmolar dengan mannitol atau saline hipertonik (3\%) sering digunakan. ${ }^{8}$ Saat melakukan tindakan anestesi pada sindrom crouzon, harus dilakukan langkah-langkah mengantisipasi dan mempersiapkan penanganan jalan napas yang sulit. Pada anak-anak, obstruksi jalan napas dapat terjadi lebih dini saat induksi, karena lidah menghalangi rongga mulut yang hipoplastik, dan dengan demikian diperlukan jalan nafas tambahan seperti tube naso atau orofaringeal atau masker atau pipa laring. Mandibula biasanya tidak mengalami kelainan pada sindrom ini dan oleh karena itu laringoskopi biasanya dapat dilakukan. ${ }^{9}$ Aspek paling menantang pada kasus sindroma Crouzon adalah manajemen jalan nafas pada setiap pembedahan yang dilakukan dengan anestesi umum. ${ }^{10}$

Sindrom crouzon, yang dinamai menurut ahli bedah saraf Perancis Oktaf Crouzon adalah kelainan genetik dominan autosomal ditandai dengan disostosis kraniofasial,dimana terjadi fusi dini dasar tengkorak menyebabkan hipoplasia midfasial, orbita yang dangkal, prognatisme mandibula, kepadatan gigi atas, langit-langit melengkung tinggi, dan terkadang obstruksi jalan napas. ${ }^{11,12}$ Pasien-pasien ini dapat datang ke fasilitas kesehatan untuk operasi rekonstruksi dan operasi yang tidak terkait lainnya. Sehingga tantangan untuk seorang ahli anestesi terutama adalah menghadapi jalan napas yang sulit.

Pada kasus ini pasien seorang bayi usia 5 bulan datang dengan keluhan kepala membesar sejak 2 bulan sebelum rumah sakit. Sewaktu lahir kraniosinostosis belum terdeteksi, dan kepala membesar akibat hidrosefalus yang dapat terjadi pada kraniosinostosis akibat abnormalnya hidrodinamik cairan serebrospinal, yang dapat diakibatkan oleh terhambatnya perkembangan fosa posterior, stenosis foramen jugular sehingga menyebabkan hipertensi drainase vena. ${ }^{6,7}$ Hidrosefalus terjadi sekunder akibat defek formasi kranium, sehingga pada kebanyakan kasus hidrosefalus bersifat nonprogresif. Kebanyakan ventrikulomegali pada sindrom crouzon bersifat asimtomatik dan tidak memerlukan penanganan, kecuali bila ada bukti jelas kenaikan tekanan intrakranial. Pelebaran fronto-orbita dan sistem shunt adalah terapi pilihan. ${ }^{6}$

Pada pasien ini tidak ditemukan kelainan kongenital lainnya, setelah dilakukan pemeriksaan fisik dan penunjang untuk menyingkirkan adanya kelainan sistemik yang mungkin dijumpai. Sehingga pemberian obatobatan anestesi baik volatil maupun intravena diasumsikan akan berjalan sebagaimana fisiologi pada bayi normal pada usia yang sama. Dan karena tidak ditemukan kelainan kongenital lainnya maka pasien ini tergolong nonsindromik kraniosinostosis. Aspek paling menantang pada kasus sindroma crouzon adalah manajemen jalan nafas pada setiap pembedahan yang dilakukan dengan anestesi umum. Kelainan anatomis yang dapat dijumpai adalah hipertelorisme, orbita dangkal, eksoftalmos, strabismus, hidung paruh, bibir atas lebih pendek, maksilla yang hipoplastik, mandibular prognathism, hipoplasia daerah tengah muka (midfasial), dan obstruksi jalan nafas atas. ${ }^{13}$ Manajemen jalan nafas dapat menjadi sulit karena adanya lengkung palatum yang meninggi, gerak leher yang terbatas, penyempitan nasofaring dan kelainan cincin trakea. ${ }^{13}$ Pada pasien ini dipersulit lagi dengan adanya hidrosefalus, pada bayi ini dijumpai lingkar kepala $52 \mathrm{~cm}$. Telah dilakukan antisipasi 
dan perencanaan untuk menghadapi jalan nafas yang sulit dengan persiapan alat-alat termasuk bougie anak, dan kemudian ternyata bermanfaat karena harus dilakukan intubasi trakea ulang karena ketidaksesuaian ukuran pipa endotrakea.

\section{Simpulan}

Penatalaksanaan pasien sindrom crouzon sangat menantang sehingga perlu dilakukan konseling pasien, antisipasi difficult airway dan rencana alternatif serta pendekatan multidisiplin. Induksi anestesi sebaiknya dilakukan oleh ahli anestesi yang berpengalaman dibantu penolong yang terampil dan bila diperlukan didampingi ahli THT. Pada kasus pasien bayi dengan sindrom crouzon dan mengalami hidrosefalus sehingga dibutuhkan tindakan operasi berupa vp-shunt. Kegagalan dalam pengamanan jalan nafas terutama pada pasien dengan peningkatan tekanan intrakranial tentu akan sangat berdampak buruk. Pada kasus ini telah dilakukan antisipasi kesulitan intubasi sehingga tindakan anestesi dan operasi berhasil sesuai yang diharapkan.

\section{Daftar Pustaka}

1. Ahmed I, Afzal A. Diagnosis and evaluation of crouzon syndrome.J Coll Phys Surg Pak 2009;19(5):318-20.

2. Cohen MM Jr. Kreiborg S. Birth prevalence studies of the crouzonsyndrome: comparison of direct and indirect methods. Clin Genet.1992;41(1):1-5.

3. Rutland P, Pulleyn LJ, Reardon W. Identical mutations in the FGFR2 gene cause both pfeiffer and crouzon syndrome phenotypes. NatGenet. 1995;9(2):173-76.

4. Wilkie AO, Slaney SF, Oldridge M. Apert syndrome results fromlocalized mutations of FGFR2 and is allelic with crouzon syndrome.
Nat Genet. 1995;9(2):165-72.

5. Bowling EL, Burstein FD. Crouzon syndrome. Optometry.2006;77(5):217-22.

6. Cinalli G, Sainte-Rose C, Kollar EM, Zerah M, Brunelle F, Chumas P, et al. Hydrocephalus and craniosynostosis. J Neurosurg 1998; 88:209-214.

7. Sainte-Rose C, LaCombe J, Pierre-Kahn A, Renier D, Hirsch JF. Intracranialvenous sinus hypertension: cause or consequence of hydrocephalus in infants? J Neurosurg 1984;60:727-736.

8. Nienaber J. Anaesthesia for ventriculoperitoneal shunts. Southern African Journal of Anesth Analg, 2011;17:1, 73-5.

9. Roche J, Frawley G, Heggie A. Difficult tracheal intubation induced by maxillary distraction devices in craniosynostosis syndromes. Paed Anesth 2002; 12: 227-34.

10. Kumar A, Goel N, Sinha C, Singh A. Anestheticimplications in a child with crouzon syndrome. Anesth Essays Res2017;11:246-7.

11. Hlongwa P. Early orthodontic management of Crouzon syndrome: Acase report. J Maxillofac Oral Surg 2009;8:74-6.

12. Hughes C, Thomas K, Johnson D, Das S. Anesthesia for surgery related to craniosynostosis: A review. Part 2. Paediatr Anaesth 2013;23:22-7.

13. Sirotnak J, Brodsky L, Pizzuto M. Airway obstruction in the Crouzonsyndrome: case report and review of the literature. Int $\mathrm{J}$ PediatrOtorhinolaryngol 1995; 31:235-46. 